increase in Ukraine. The same disappointing figures are in place for the legalization (laundering) of proceeds of crime.

To a large extent, this is due to the general deterioration of the country's criminogenic situation and the establishment of a financial monitoring system in Ukraine, with the presence of a number of unresolved problems in this regard. We are currently witnessing the active development of financial legislation and the government's attempt to prevent and counteract the actual legalization (laundering) of proceeds of crime, terrorist financing and the proliferation of weapons of mass destruction.

It is noted that this negative phenomenon is widespread. Emphasis is placed on the transnational nature of "laundering" of dirty money. Virtually every civilized state tries to put in place an effective financial monitoring system. This system has its own characteristics depending on the country, but there are common features. They are, among other things, manifested in functions and principles. The ways of improving the activity of the financial monitoring system are proposed.

Key words: financial monitoring, counteraction to legalization of income, money laundering, public administration function.

DOI: $10.33766 / 2524-0323.88 .257-265$

УДК 343.98

В. М. Плетенець, кандидат юридичних наук, доцент, доцент кафедри криміналістики, судової медицини та психіатрії

Дніпропетровського державного університету внутрішніх справ

(м. Дніпро, Україна)

e-mail: viktor_plet@i.ua

iDhttps://orcid.org/0000-0002-3619-8624

\title{
МОЖЛИВОСТІ ВИКОРИСТАННЯ СЛІДЧИМ КРИТИЧНОГО МИСЛЕННЯ В УМОВАХ ПРОТИДІЇ РОЗСЛІДУВАННЮ
}

Стаття присвячена висвітленню можливостей використання слідчим критичного мислення в умовах протидії розслідуванню.

Наголошується, що процедури та стратегії критичного мислення мають використовуватися для вирішення неординарних практичних завдань, котрі неможливо вирішити машинально, із застосуванням наявних знань та умінь. Звертається увага на те, що набуття слідчими навичок оцінки кожного розслідуваного кримінального провадження сприятиме формуванню такого якісного рівня, що не дозволить припуститися помилок розслідування. Підкреслюється, що постійний тиск з боку зацікавлених осіб не повинен впливати на рішення слідчого, які мають бути самостійними та грунтуватися на критичному аналізі матеріалів провадження.

Ключові слова: протидія розслідуванню, критичне мислення, рішення слідчого, аналіз провадження.

Постановка проблеми. Діяльність слідчого має пізнавально-пошуковий характер пізнання події минулого, що здійснюється шляхом збору відомостей (с) Плетенець В. М., 2019 
про неї. Виявлені дані аналізуються на предмет відношення до розслідуваного кримінального провадження. За значною кількістю проваджень зустрічаються невідповідності у свідченнях допитуваних осіб, відсутність знаряддя вчинення злочину, що логічно пояснюються слідчими як зайнята стороною захисту лінія поведінки, застосування підготовки та маскування вчинення кримінального правопорушення. Фальсифікації ж місць події, наприклад за вбивствами, є розповсюдженим явищем. Однак i за іншими, менш резонансними кримінальними правопорушеннями відкидати можливості зацікавлених осіб у формуванні обстановки місця події не варто. Це обумовлює необхідність критичної оцінки кожного кримінального провадження.

Аналіз останніх досліджень i публікацій. Критичне мислення досліджувалось у різних науках: психології, педагогіці, логіці, криміналістиці та інших. Иому приділяли увагу такі вчені, як: М. Н. Алексєєв, В. П. Борисенков, О. Ю. Булулуков, А. П. Валицька, Н. В. Вукіна, С. Д. Максименко, В. М. Монахов, О. І. Пометун, Я. А. Пономарьов, О. К. Тихомиров, Х. Г. Тхагапсоєв та багато інших.

У той же час питанням критичного мислення при розслідуванні в умовах протидії цій діяльності з боку зацікавлених осіб належної уваги науковцями приділено не було. Це обумовлює труднощі, з якими стикаються правоохоронщі в організації своєї діяльності, в умовах проявів протидії розслідуванню.

Так, згідно зі статистичними даними Генеральної прокуратури України [1], підозра оголошується приблизно у 25 \% від загальної кількості зареєстрованих кримінальних правопорушень. На результати розслідування, визначені в статистичних даних, значною мірою можуть впливати як прояви протидії розслідуванню, так і недостатньо якісний підхід до оцінки матеріалів та організації кримінального провадження. У результаті цього, за даними деяких дослідників [2], в Україні реєструються близько 1 \% виправдувальних вироків.

Формування цілей. Метою даної статті $є$ окреслення можливостей використання слідчим критичного аналізу матеріалів кримінального провадження в умовах протидії розслідуванню.

Виклад основного матеріалу. Можна сказати, що критичне мислення - це мислення високого рівня, що дозволяє ставити під сумнів інформацію, що надходить. Також його визначають як «оціночне, рефлексивне», або «мислення про мислення» [3]. Таким чином формується неупереджене ставлення до отримуваних відомостей, жодній частині з яких не надається статусу остаточного та недоторканого доказу. Критичне мислення складається 3 певних установок дослідника, які орієнтують його на врахування контексту, широту охоплення фактичної інформації тощо, а також із певних процедур, спрямованих на забезпечення логічної досконалості, фактичної обгрунтованості та ціннісної доцільності міркувань [4].

Процедури та стратегії критичного мислення мають використовуватися для вирішення неординарних практичних завдань, котрі неможливо вирішити механічним застосуванням наявних знань та умінь. Так виявлення в діяльності слідчого нового та незрозумілого, чим зокрема може бути виявлення факту протидії розслідуванню, що мала прихований, системний характер, формуватиме 
проблемну ситуацію та обумовлюватиме неординарні завдання їі вирішення. При цьому слідчий може зіткнутися з ситуацією, коли лише один предмет, допит чи висновок експерта ставить під сумнів раніше сформовану уяву про вчинену подію. У даному випадку отримані дані мають критично оцінюватися на відповідність кожного з них окремо та в сукупності події, що сталася.

У проблемних ситуаціях, як наголошують І. П. Чередниченко та Н. В. Тельних, завжди виникають такі цілі, для досягнення яких наявних засобів, способів і знань виявляється недостатньо [5, с. 138]. Варто зазначити, що, наприклад, типові слідчі ситуації початкового етапу розслідування злочинів поділяються науковцями, у тому числі, з позиції проблемності. У той же час проблемність ситуації $є$ оціночним показником труднощів у діяльності слідчих, які необхідно здолати. Саме наявні в них досвід, знання, навички, цілеспрямованість та інші якості визначають суб'єктивність та відповідним чином впливають на процес розкриття та розслідування злочинів [6, с. 100]. Об'єктивні фактори також оцінюються через зазначені якості слідчого. Відповідно, те, що для одного слідчого не складатиме жодних труднощів, для іншого буде нездоланною перепоною в діяльності. Таким чином, труднощі викликає не існування проблемної ситуації як такої, а ії сприйняття та пошук шляхів вирішення конкретним слідчим з позиці наявних знань, досвіду, зокрема, позитивного чи негативного.

Отже, критичного мислення потребують не будь-які задачі, але лише ті, для розв'язання яких наявних знань та навичок недостатньо [7, с. 50]. Однак, варто зазначити, що кожне кримінальне провадження є індивідуальним, а повторюваність може простежуватися лише в 3 загальних рисах. Тому вирішення кожного провадження несе в собі труднощі та обумовлює, на нашу думку, необхідність критичного аналізу його матеріалів, а зрозумілій, на перший погляд, ситуації має приділятися не менше уваги, ніж проблемній, оскільки без цього може бути втрачений всебічний, неупереджений підхід до оцінки зібраних матеріалів та власної діяльності слідчим.

За умов якщо, наприклад, у провадженні все нібито «складається» добре (на місці події виявляється значна кількість слідів, особи зізнаються в причетності до вчиненого кримінального правопорушення, захисники не чинять протидії, розслідування ведеться без зайвих зусиль), слідчий, скоріше за все, сприйматиме ситуацію безпроблемною, не замислюючись про те, що обстановку могли штучно сформувати, чи то провину на себе візьме непричетна до вчиненого кримінального правопорушення особа, чи то захисник обере тактику, спрямовану на т. зв. «присипляння» пильності слідчого тощо.

У суді ж виявиться, що, окрім зізнання самого обвинуваченого, доказів для проголошення йому вироку недостатньо. Уникнення подібного явища можливе шляхом есебічної, грунтовної оцінки матеріалів кримінальних проваджень.

Як наголошуе Ф. А. Станкато, критичне мислення - це формулювання суджень відносно правдивості та реальності заяв або відповідей щодо розв'язання проблем [8]. Виявлені невідповідності сформованої картини правопорушення та припущення про його механізм, має поставити перед слідчим питання про належність відповідних предметів (об'єктів, свідчень) щодо розслідуваного кримінального провадження. Сформоване раніше в 
слідчого бачення картини вчиненого суспільно-небезпечного діяння не повинно бути догмою та має піддаватися сумніву й перегляду.

Саме суперечлива ситуація, на думку Д. Клустер, є пусковим механізмом критичного розмірковування [9, с. 3]. У даному випадку формуються умови складного вибору - залишити ситуацію такою, як вона сприймається на перший погляд, або спробувати ії переосмислити. Це може потягти за собою необхідність корекціїі планів розслідування, проведення слідчих (розшукових) дій повторно чи додатково тощо.

Критичне мислення виступає як нестандартне, що грунтується на можливості «...бачити й оцінювати альтернативи...». [10, с. 5]. При цьому усвідомлення альтернатив має сприяти пошуку шляхів вирішення складних ситуацій, що виникають у ході розслідування. Відшукування в матеріалах кримінального провадження тих маркерів, що стануть відправними точками в подальшому розслідуванні потребує критичного аналізу з боку слідчих.

Так на питання про вірогідне подальше здійснення критичного аналізу матеріалів провадження стверджувальну відповідь дали 21 \% проінтервйованих слідчих, із яких лише 27 \% роблять це у всіх провадженнях, інші (73 \%) - лише по тих справах, що викликають труднощі. Відповідно, отримані відомості по кримінальному провадженню здебільшого не будуються на їхній критичній оцінщі, а пошук пояснень протиріч відбувається шляхом механічного застосування накопичених знань та досвіду. Слідчий оцінює об'єкти що потрапляють у поле його зору, з позиції ступеня надійності інформації та ії належності до події. Таким чином, суб'єкт приписує цінність певному об'єкту [11, с. 141]. У той же час слідчі мають критично ставитися до всіх виявлених об'єктів та оцінювати їх відношення до провадження. Слідчому постійно доводиться здійснювати переходи від обмірковування до дій та в зворотньому напрямку, від швидкості яких залежить результативність його діяльності та що є показником інтелектуальної активності.

Заслуговують на увагу проведені дослідження, згідно з якими можна визначити рівень інтелектуальної активності слідчих, їхню високу кваліфікацію, а саме:

-23\% - «nасивні» («репродуктивні»), для яких час вирішення завдань скорочується в основному за рахунок тренування; несподівані ж варіанти ситуації викликають збільшення часу на розв'язання;

- 67\% - «евристичні», для яких характерне прагнення ввести нові способи вирішення й скоротити час розв'язання завдань головним чином за рахунок формальних прийомів;

- 6\% - «креативні» - мають вищий рівень інтелектуальної активності, пов'язаний із ініціативою в постановці завдань, із прагненням до виявлення причинов-наслідкових зв'язків і закономірностей, до теоретичних узагальнень, із пошуком сенсу, причини одержуваного ефекту, із дослідженням завдання без турботи про час іiі рішення [12]. При цьому фактор часу має значення не тільки з позиції кримінального процесу, а й організації діяльності та криміналістичної тактики. Упущення необхідного моменту проведення якоїсь запланованої процесуальної дії може поставити під загрозу можливість закріпити отримані 
відомості в процесуальній формі. Таким чином, час на обдумування та прийняття рішень обмежений, що особливо гостро відчувається на початковому етапі розслідування, а також у разі виявлення проявів протидії розслідуванню.

Час накладає свої обмеження на можливості приділення належної уваги кожному кримінальному провадженню, особливо якщо їх одночасно декілька сотень перебуває в слідчого; учитися на них шляхом спроб та помилок, витрачаючи час, сили та засоби, не має можливості. Так, від помилок та спроб їх виправлення ніхто не застрахований, однак вони можуть зводитися до мінімуму шляхом застосування критичного аналізу матеріалів провадження. Прикладом недостатньо критичного аналізу та належного ставлення до розслідування можуть бути справи пологівського маніяка С. Ткача, суспільно-небезпечні діяння якого відбувалися протягом 25 років (37 вбивств, а за деякими оцінками - понад 100), за що відбували покарання щонайменше 11 осіб [13]. Способи (підготовка, безпосереднє вчинення та маскування) та обстановка (місце та час) злочинної діяльності визначалися злочинцем, виходячи 3 усвідомлення механізму слідоутворення та наявних спеціальних криміналістичних знань. Так місця вчинення кримінальних суспільно-небезпечних діянь обиралися безлюдні (поруч 3 автомагістралями, залізничними коліями), які використовувалися дпя залишення місця події, що унеможливлювало роботу службово-розшукових собак; сліди на місці події затоптувалися, а предмети, на яких могли утворюватися відображення, вилучалися. Спостереження за діями слідчо-оперативної групи (а за деякими епізодами С. Ткач був запрошений у якості понятого), надавало можливість з'ясування виявлених у ході огляду відображень його дій, предметів, виявлених свідків-очевидців. На підставі отриманих даних відбувалася корекція подальших злочинних дій та приймалися заходи з протидії розслідуванню. У разі достатньої поінформованості злочинця щодо наявних у матеріалах провадження даних, які можуть стати підгрунтям для його звинувачення, притягнути до відповідальності злочинця майже неможливо. Стороною захисту ці відомості можуть або спростовуватися, ставитися під сумнів законність їх отримання або використовуватися для формування алібі. Так неодноразово допитаний на предмет причетності до вчинених суспільно-небезпечних діянь С. Ткач висував алібі, котрі правоохоронщі не могли спростувати, що обумовлювало уникнення його від відповідальності. 3 іншої сторони, резонанс даних злочинів накладав свій відбиток на дії співробітників правоохоронних органів. Так тиск 3 боку контролюючих органів, ЗМІ, громадськості, про рівень яких можна лише здогадуватися, не міг не вплинути на прийняття помилкових, поспішних рішень правоохоронцями.

Отже, даний приклад демонструє проблему критичного аналізу матеріалів провадження співробітниками правоохоронних органів i, відповідно, складність прийняття ними обгрунтованих рішень в умовах протидії розслідуванню. Наявність власної позиції може характеризувати слідчого як сформовану, зрілу особистість у розстановці пріоритетів, а прийняття самостійних рішень демонструє принциповість його позиції. Формулювання самостійних суджень як продукту критичного мислення означає, що воно спрямоване на творчу, мисленнєву діяльність, а не на репродуктивне мислення, що базується на жорстких алгоритмах і стереотипах [14, с. 8]. 
3 принциповістю, як рисою характеру слідчого, пов'язуються наявність твердих переконань та активне прагнення до їх реалізації, незважаючи на перепони та загрозу особистому благополуччю. Так якщо аналіз провадження виконувати з позиції захисника, відшукуючи прогалини, то це сприятиме слідчому у виявленні допущених прорахунків. Набуття слідчими навичок подібної оцінки кожного кримінального провадження забезпечить формування такого якісного рівня, що не дозволить припускатися помилок розслідування.

Незважаючи на постійний тиск з боку зацікавлених осіб, рішення слідчого мають бути самостійними та грунтуватися на критичному аналізі матеріалів провадження. У цьому випадку можлива реалізація завдань кримінального провадження, як зазначено в ст. 2 КПК України: «....3 тим, щоб кожний, хто вчинив кримінальне правопорушення, був притягнутий до відповідальності в міру своєї вини, жоден невинуватий не був обвинувачений або засуджений...».

Висновки. Проведене нами дослідження дає можливості наголосити, що критичне мислення має стосуватися всіх матеріалів провадження, а не тільки тих, у яких слідчий відчуває проблеми в їх розслідуванні. Цим буде забезпечений усебічний, неупереджений підхід до оцінки зібраних матеріалів та власної діяльності слідчим.

Незважаючи на прояви протидії розслідуванню з боку зацікавлених осіб, аналіз кримінального провадження має бути критичним, а рішення слідчого самостійними та обгрунтованими. Усе зазначене сприятиме мінімізації витрат часу, сил та засобів, що, у свою чергу, сприятиме підвищенню якості розслідування.

Подальші наші дослідження зосереджуватимуться на розгляді можливостей факторного аналізу в подоланні проявів протидії розслідуванню.

\section{Використані джерела.}

1. Сдиний звіт про кримінальні правопорушення України. URL: http://www.gp.gov.ua/ua/stat.html.

2. Практичний погляд на відсутність виправдувальних вироків в Україні: URL: http://uz.ligazakon.ua/ua/magazine_article/EA010378

3. Критичне мислення: що це таке? URL: https://virgo.org.ua/index.php/psikholo giya/3042-kritichne-mislennya-shcho-tse-take

4. Терно С. О. Теорія розвитку критичного мислення (на прикладі навчання історії) /С. О. Терно: посібник для вчителя. Запоріжжя: Запорізький національний університет, 2011. 105 c. URL: http://sites.znu.edu.ua/interactiv.edu.lab/125.ukr.html

5. Чередниченко И. П. Психология управления / Серия «Учебники для высшей школы»/ И. П. Чередниченко, Н. В. Тельных. Ростов-на-Дону: Феникс, 2004. 608 с.

6. Плетенець В. М. Розслідування завідомо неправдивих повідомлень про загрозу безпеці громадян, знищення чи пошкодження об'єктів власності: монограф. / В. М. Плетенець. Дніпропетровськ: Дніпроп. держ. ун-т. внутр. справ, 2012. 248 с.

7. Заботин В. В. Этап усмотрения проблемы в обучении (В помощь учителю и студенту) / В. В Заботин. Владимир: Владимирский государственный педагогический институт им. П. И. Лебедева-Полянского, 1973. 187 с.

8. Stancato F. A. Tenure, Academic Freedom and the Teaching of Critical Thinking / F. A. Stancato / / College Student Journal. September, 2000.

URL: http://findarticles.com/p/articles/mi_m0FCR/is_3_34/ai_66760558/ 
9. Клустер Д. Что такое критическое мышление / Д. Клустер / / М. : Русский язык. 2002. № 29. С. 3-8. URL: http://rus.1september.ru/ 2002/29/2.htm

10. Пометун О. Формування критичного мислення учнів на уроках з курсу за вибором «Права людини» / О. Пометун / / Історія в школах України. 2008. № 9. С. 5-7.

11. Краткий словарь по логике / Д. П. Горский, А. А. Ивин, А. Л. Никифоров ; под ред.Д. П. Горского. М. : Просвещение, 1991. 208 с.

12. Профессиональные качества следователя. URL: https://studfile.net/preview/2 893434/page:20/

Ткач Сергей Федорович. N.d. N.p.URL: https:/ / ru.wikipedia.org/wiki/

15. Технології розвитку критичного мислення учнів / Кроуфорд А., Саул В., Метьюз С., Макінстер Д.; Наук. ред., передм. О. І. Пометун. К.: Вид-во «Плеяди», 2006. 220 с.

\section{References:}

1. Jedynyj zvit pro kryminal'ni pravoporushennja Ukrai'ny. N. d. gp.gov.ua URL: http://www.gp.gov.ua/ua/stat.html. [in Ukrainian].

2. Praktychnyj pogljad na vidsutnis' vypravduval'nyh vyrokiv v Ukraine. N. d. uz. liga zakon. ua URI: http:/ / uz.ligazakon.ua/ua/magazine_article/EA010378. [in Ukrainian].

3. Krytychne myslennja: shho ce take? N. d. virgo.org.ua URL: https://virgo.org.ua/index.php/psikhologiya/3042-kritichne-mislennya-shcho-tse-take. [in Ukrainian].

4. Terno, S. O. (2011). Teorija rozvytku krytychnogo myslennja (na prykladi navchannja istorii'). S. O. Terno (Ed.). Zaporizhzhja: Zaporiz'kyj nacional'nyjuniversytet. URL: http://sites.znu.edu.ua/interactiv.edu.lab/125.ukr.html. [in Ukrainian].

5. Cherednichenko, I. P. (2004). Psihologija upravlenija. I. P. Cherednichenko, N. V. Tel'nyh. (Eds.). Rostov-na-Donu: Feniks. [in Russian].

6. Pletenec,' V. M. (2012). Rozsliduvannja zavidomo nepravdyvyh povidomlen' pro zagrozu bezpeci gromadjan, znyshhennja chy poshkodzhennja ob'jektiv vlasnosti. Dnipropetrovs'k: DSUIA [in Ukrainian].

7. Zabotin, V. V. (1973). Jetap usmotrenija problemy v obuchenii (V pomoshh' uchitelju i studentu). V. V. Zabotin (Ed.). Vladimir: Vladimirskij gosudarstvennyj pedagogicheskij institut im. P. I. Lebedeva-Poljanskogo [in Russian].

8. Stancato, F. A. (2000). Tenure, Academic Freedom and the Teaching of Critical Thinking / F. A. Stancato (Ed.). College Student Journal. September. URL: http://findarticles.com/p/articles/mi_m0FCR/is_3_34/ai_66760558/. [in Americanian].

9. Kluster, D. (2002). Chto takoe kriticheskoe myshlenie Russkij jazyk - Russian language, 29, 3-8. URL: http:/ / rus.1september.ru/ 2002/29/2.htm. [in Russian].

10. Pometun, O. (2008). Formuvannja krytychnogo myslennja uchniv na urokah z kursu za vyborom «Prava ljudyny» Istorija v shkolah Ukrai'ny - History in Ukrainian schools, 9, 5- 7. [in Ukrainian].

11. Gorskij, D. P., Ivin, A. A., Nikiforov, A. L. (1991). Kratkij slovar' po logike. Moskva: Prosveshhenie. [in Russian].

12. Professional'nye kachestva sledovatelja. N. d. studfile.net URL: https://studfile.net/previesh/2893434/page:20/. [in Russian].

13. Tkach, Sergej Fjodorovich. N. d. ru.shikipedia.org. URL: https://ru.shikipedia.org/shiki/ [in Ukrainian].

14. Tekhnolohii rozvytku krytychnoho myslennia uchniv/ (2006). Krouford, A., Saul, V., Met'juz, S., Makinster, D. (Eds.) et al. O. I. Pometun (Ed.) Kyiv: Plejady. [in Ukrainian]. 
Плетенец В. Н,

кандидат юридических наук, доцент, доцент кафедры криминалистики, судебной медицины и психиатрии Днепропетровского государственного

университета внутренних дел

(г. Днепр, Украина)

\section{ВОЗМОЖНОСТИ ИСПОЛЬЗОВАНИЯ СЛЕДОВАТЕЛЕМ КРИТИЧЕСКОГО МЫШЛЕНИЯ В УСЛОВИЯХ ПРОТИВОДЕЙСТВИЯ РАССЛЕДОВАНИЮ}

Статья посвящена освещению возможностей использования следователем критического мышшения в условиях противодействия расследованию. Отмечается, что процедуры и стратегии критического мышления должны использоваться для решения неординарных практических задач, которые невозможно решить машинальным применением имеющихся знаний и умений. Обращается внимание на то, что приобретение следователями навыков оценки каждого расследуемого уголовного производства будет способствовать формированию такого качественного уровня и не позволит допустить ошибок расследования. Подчеркивается, что постоянное давление со стороны заинтересованных лиц не должно влиять на решение следователя, которым надлежит быть самостоятельными и сформированными на критическом анализе материалов производства.

Ключевые слова: противодействие расследованию, критическое мышление, решение следователя, анализ производства.

Pletenets V., Candidate of Law, Associate Professor, Associate Professor of the Department of criminalistics, forensic medicine and psychiatry of Dnepropetrovsk State

University of Internal Affairs

(Dnipro, Ukraine)

\section{THE POSSIBILITIES FOR THE INVESTIGATOR TO USE CRITICAL THINKING IN THE CONTEXT OF COUNTERING INVESTIGATION}

The article is devoted to highlighting the possibility of the investigator using critical thinking in the context of counteracting the investigation.

It is noted that falsification of places of occurrence, both on murders, and other criminal offenses is common. This requires a critical evaluation of each criminal proceeding.

Attention is drawn to the fact that the findings of the investigator in the activities of the incomprehensible, new, from the point of view of available knowledge and experience can be perceived as a problem situation. The investigator can then experience the situation when only

It is stressed that the difficulty is not the existence of a problem situation per se, but its perception and the search for solutions by a particular investigator based on available knowledge, experience, in particular, positive or negative. It is noted that the discrepancies found between the current pattern of the offense and the assumption of its mechanism should raise the question of the belonging of the items concerned to the investigator (facilities, certificates) to the criminal proceedings under investigation. 
The investigator's vision of a picture of a socially dangerous act, which was developed earlier, cannot be dogmas and must be questioned and reconsidered.

It is stated that the awareness of alternatives should help to find solutions to the complex situations that arise during the investigation. The search for markers in criminal proceedings that will become the starting points in the further investigation requires critical analysis by investigators. It is noted that the investigator constantly has to carry out transitions from thinking to actions and in the opposite direction. Their speed determines the effectiveness of the investigator's activities and is an indicator of intellectual activity.

The case of S. Tkach being analyzed Law enforcement officers to use critical analysis of materials in a context of opposition to the investigation.

It is noted that the analysis of the proceedings from the position of the defense counsel, looking for gaps, will help the investigator to identify the shortcomings.

The ability of investigators to evaluate each criminal proceeding in such a way will prevent the mistakes of the investigation. It is stressed that constant pressure from interested persons should not affect the decision of the investigator. They should be independent and based on a critical analysis of production materials.

Key words: Counteraction of investigation, critical thinking, decision of investigator, analysis of the proceedings.

DOI: $10.33766 / 2524-0323.88 .265-277$

УДК 336.025:347.73

В. Д. Пчолкін, доктор юридичних наук, професор, професор кафедри кримінального процесу, криміналістики та експертології

Харківського національного університету внутрішніх справ (м. Харків, Україна) e-mail: pchelkinv@ukr.net

(iD) https://orcid.org/0000-0002-3379-5036

О. В. Федосова, кандидат юридичних наук, старший науковий співробітник, головний науковий співробітник науково-дослідної лабораторії з проблем протидії злочинності Харківського національного університету внутрішніх справ

(м. Харків, Україна)

e-mail: elvafedosova@gmail.com

(iD https://orcid.org/0000-0002-5577-8333

\section{ТАКТИЧНІ ОПЕРАЦІЇ ПРИ РОЗСЛІДУВАННІ ЗЛОЧИНІВ ЕКОНОМІЧНОÏ СПРЯМОВАНОСТI}

У статті розглянуто поняття та сутність тактичних операцій при розслідуванні злочинів економічної спрямованості. Проаналізовано теоретичну концепцію щодо ролі й місця цієї наукової категорії в системі криміналістики. Визначено наукові

(С) Пчолкін В. Д.,

Федосова О. В., 2019 